Copyright (C) 2018 by Academic Publishing House Researcher

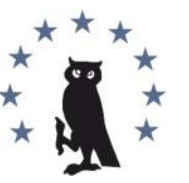

Published in the Russian Federation

European Researcher. Series A

Has been issued since 2010.

ISSN 2219-8229

E-ISSN 2224-0136

2018, 9(4): 291-297

DOI: $10.13187 /$ er.2018.4.291

www.erjournal.ru

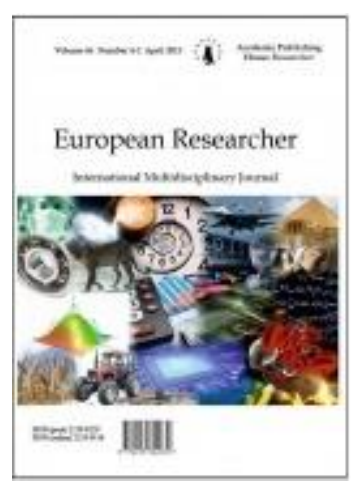

\title{
Trends in the Business Development and Investment Dynamics in Kazakhstan at the Present Stage
}

\author{
Aslanbek Dzhakupov a, Diana Ismailova a , *
}

${ }^{a}$ Central Bohemia Institute of Applied Science and Management, Prague, Czech Republic

\begin{abstract}
The relevance of the topic chosen is obvious, because the market economy cannot exist without business. It is already an accomplished fact of the experiencing great difficulties in entrepreneurship of modern Kazakhstan. It is protected by law and will be developed. The authors reflected in their research the essence of the business, its advantages and disadvantages, current status and development trends. The practical part is describing all the organizational framework. And carefully, describing every sector starting from the Sales department, Research and Development department, Purchase department, Assembly hall, and service department. During the time composing the article, I met in person all workers responsible and gave them short presentation how their procedure is overlooking ISO plan.
\end{abstract}

Keywords: economy, investment, entrepreneurship, market competitiveness

\section{Introduction}

The transition to a market economy requires a radical transformation of the product structure, aimed at overcoming the monopoly and competition. According the world experience, we can see that the solution to this problem cannot be proves without the development of entrepreneurship, based on the different ownerships' forms.

However, the whole entire prerequisites are intensively developed entrepreneurial activity in the Republic of Kazakhstan, in particular, carried out extensive work on privatization, by which creates a solid economic foundation for the development of entrepreneurship, thus society as a whole. Owing the entrepreneurs and businesses the country thrives. At the same time, businessmen and entrepreneurs are thrive owing the government support (Auezkanov, 2009).

The decision of important problems, ensuring the development of a new layer of entrepreneurship in the regions, reflected in the Message of President of Kazakhstan Nursultan Nazarbayev on January 31, 2017 "Third Kazakhstan Modernization: global competitiveness"

\section{The main types of business activities}

Entrepreneurship as a special form of economic activity may be carried out in both the public and private sector. In accordance with this distinction:

a) state enterprise;

b) private enterprise.

\footnotetext{
${ }^{*}$ Corresponding author

E-mail addresses: idt12@mail.ru (D. Ismailova)
} 
State enterprise is a form of the economic activity on behalf of companies established: a) public authorities, which are authorized to manage state property (state owned enterprise), or b) local authorities. An important characteristic of such enterprises in favor of the fact that they are responsible for its obligations only property that is in their ownership.

Private enterprise is a form of the economic activity on behalf of the company or entrepreneur (if such activities are carried out without the employment of the workforce, in the self-employment form).

Indeed, each of these types - public and private business - has its own features, but the basic principles of their implementation are very similar. In both cases, the implementation of such activities requires initiative, responsibility, innovative approach, the pursuit of profit maximization. Typology of both types of businesses has a very similar trend yet. includes:

Entrepreneurship as a form of proactive activities aimed at profit (business income),

1) Implementation of direct productive functions, i.e. production of goods (products) or services (such as engineering firm, tourist company, the design office);

2) the implementation of mediation, i.e. services related to the goods promotion on the market and its transfer to the appropriate (socially acceptable) form of the direct producers such goods to the consumer.

Public awareness of the problem comes down to the fact that, on the one hand, the priority is the first type of business as social wealth (as a generalized result of the level and life quality for every society member) depends on the state of affairs is in the sphere material production, scientific-technical and services (Mamyrov, Ikhdanov, 1998). On the other hand, is a social relation to this type of business practice is not really the priority nature - society and contributes to the development of the second business type, i.e., mediation. Why? First of all, that the level and life quality and comfort for every society member to a large extent depend on the level of development in the society intermediary sphere (convenient for the buyer organization of trade, advertising, delivery of goods in the house, order goods by mail, telephone and so on. d).; the same applies to consumer's industrial goods (Shirshova, 2011).

But is the public perception of mediation being not the only and main reason. The main thing is different - intermediary business activities, its presence and complexity to reasonable levels is:

1) to increase the direct producer's productivity of goods based on the specialization;

2) to accelerate the turnover (circulation) capital;

3) saturation commodity markets to objectively required size and functioning of the direct producers in accordance with the consumers `interests.

Depending on the content of entrepreneurial activity and its relation to the main stages reproductive process to distinguish between different types of businesses: manufacturing, commercial, financial, mediation, insurance.

Entrepreneurship is called productive if the entrepreneur directly, using as factors implements and objects of labour, produce products, goods, services, work, information, spiritual values for subsequent sale to consumers, customers, trade organizations. Thus, the production function in this kind of business - mainly determined.

The practice of business in any form includes the innovative process. The above-cited business division typesare based on the conviction that the production and placing on the market of traditional products is also carried out with the use some new methods or techniques associated with the product organization, technical elements of production or changes in the quality characteristics of manufactured goods.

\section{The current state of entrepreneurship in Kazakhstan}

Society is increasingly aware that small and medium business is one of the key conditions for the formation of market mechanisms and is an integral part of a modern market system. Small business development in unity with diversification (splitting) industrial sector constitute one of the pillars strategy "Kazakhstan - 2030". Small business in Kazakhstan is not only a necessary step in the market creation economic system, but also the most significant element in the social transformation society.

Despite the rapid development of business in recent years, there are several problems hindering the qualitative growth of the economy. These problems include: 
- Legislation imperfection - legislation on private enterprise contains outdated rules. On several issues, the development of SMEs are no clear rules, which leads to an increase in administrative barriers and dual interpretation of the current legislation;

- Problem determination criterion businesses - criteria for classifying businesses as small and medium businesses do not correspond to international practice. They stimulate artificial "splitting" of business, reduce the effectiveness of the support measures and the competitiveness domestic business;

- Insufficient structural tax system - Tax system of Kazakhstan does not provide economic incentives for small business scale, and its gradual transformation into the middle;

- Administrative barriers - administrative barriers is a major obstacle to the development of small and medium-sized businesses. However, their complex analysis of diets keys to the most effective solution to this problem;

- Underdevelopment and fragmentation of infrastructure to support entrepreneurship existing in Kazakhstan SME support infrastructure does not provide comprehensive support for the development to small and medium-sized businesses and leads to increased transaction costs;

- Low competitiveness products of small and medium-sized businesses - insufficient assetshigh level of wear and low renewability fixed assets, as well as the low technological SME sector as a whole, reduce productivity, economic efficiency and competitiveness of the products small and medium-sized businesses;

- Access ` lack to financial resources - the global financial crisis has exacerbated the problem of funding lack for SMEs. Timely implementation of the State Stabilization Program allowed to partially neutralize the negative impact of the crisis on the SME sector (Voyevutko, 2011).

The challenges posed by the President of Kazakhstan, and implementation methods are already confirmed by the practice of the leading economies in the world.

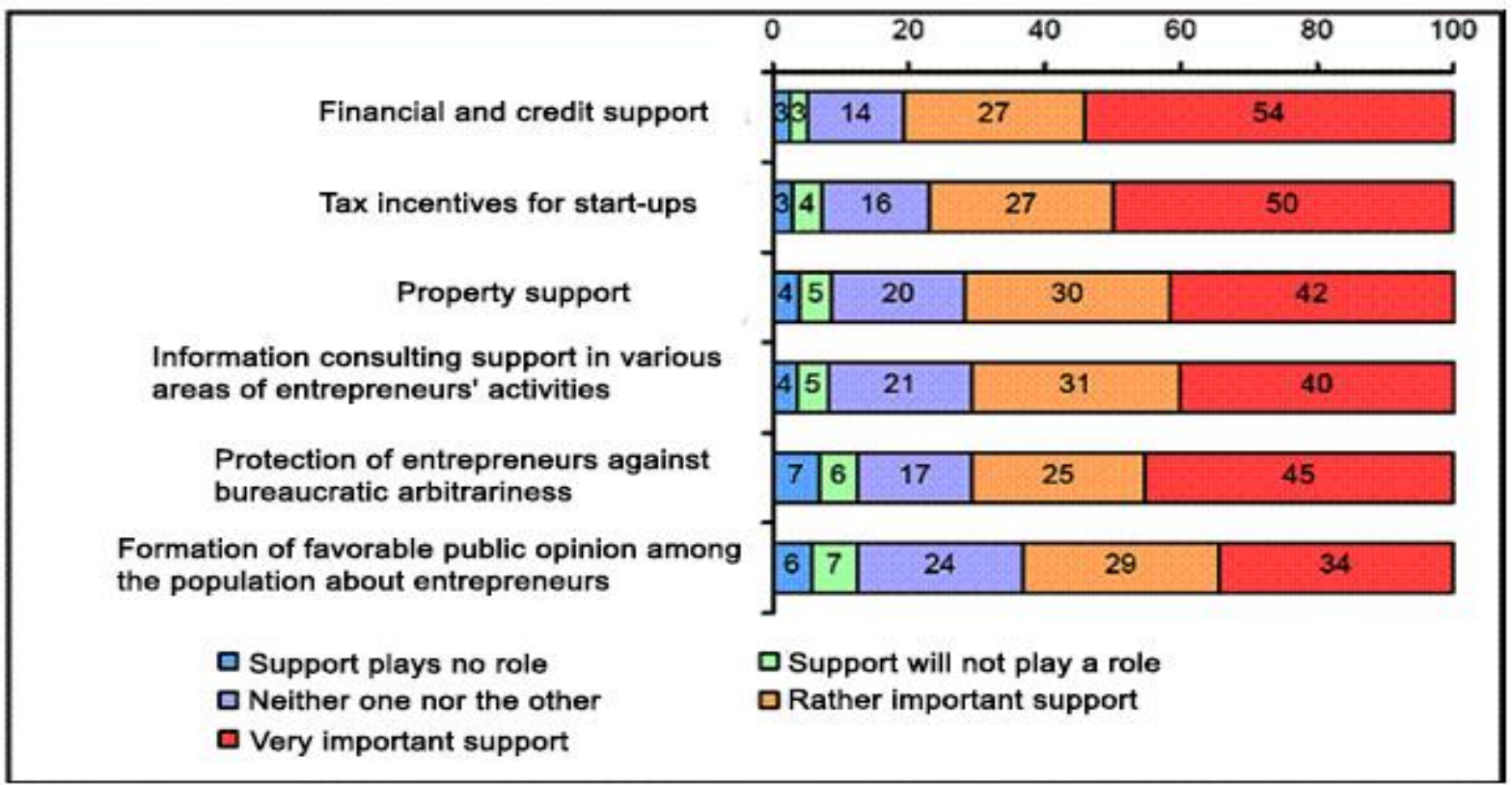

Fig. 1. Important evaluation of state support for entrepreneurship 


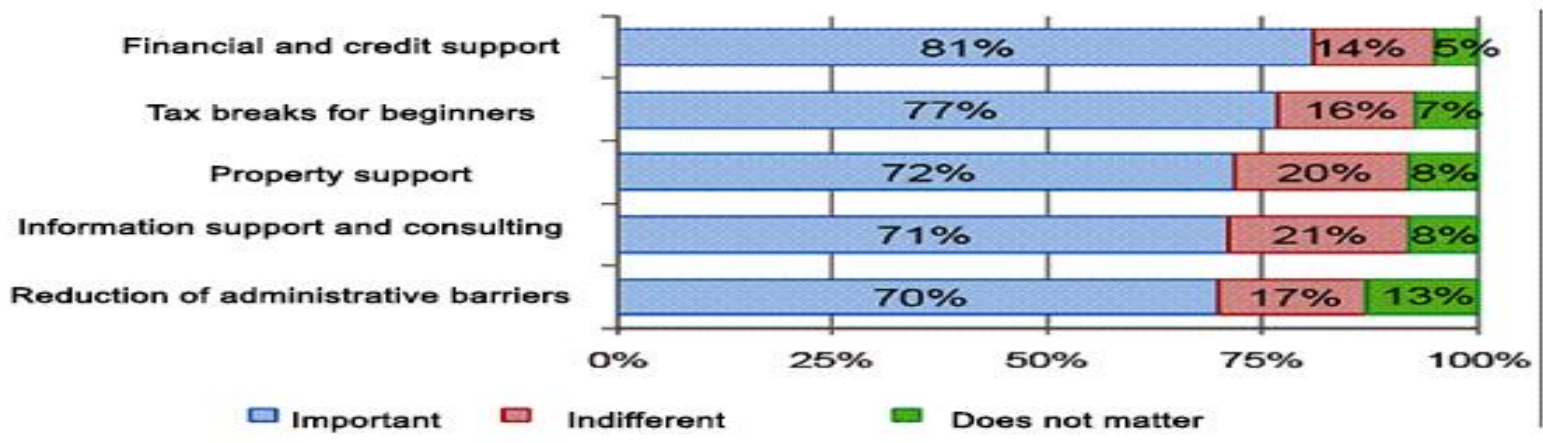

Fig. 2. Assessment of state support for entrepreneurship development importance

As can be seen from Figures 1 and 2, most entrepreneurs appreciate the importance of the test directions state support. The most important are financial and credit support and support in the form of tax incentives for business start-ups. Approximately the same number of = Kazakhstan ` businessmen (70 \%) include property support, information, consulting, support and protection entrepreneurs from bureaucratic arbitrariness in the category - the most important.

The main role is going for the development of small businesses in Kazakhstan. Nursultan Nazarbayev (the State " Head), presenting the content «Strategy «Kazakhstan-2050» said: "The domestic business is the driving force behind a new economic course. The share of small and medium-sized businesses in the economy should grow at least twice by 2030. Firstly, we have to create conditions so that man could try his hand in business, to become a full participant in the country's economic reforms, rather than wait for the state will solve all the problems for him. It is important to raise the overall level of business culture and encourage entrepreneurial initiative. "

The number of small and medium-sized businesses is growing up in our country every year. This is best evidenced by the statistics.

Number of active SME units

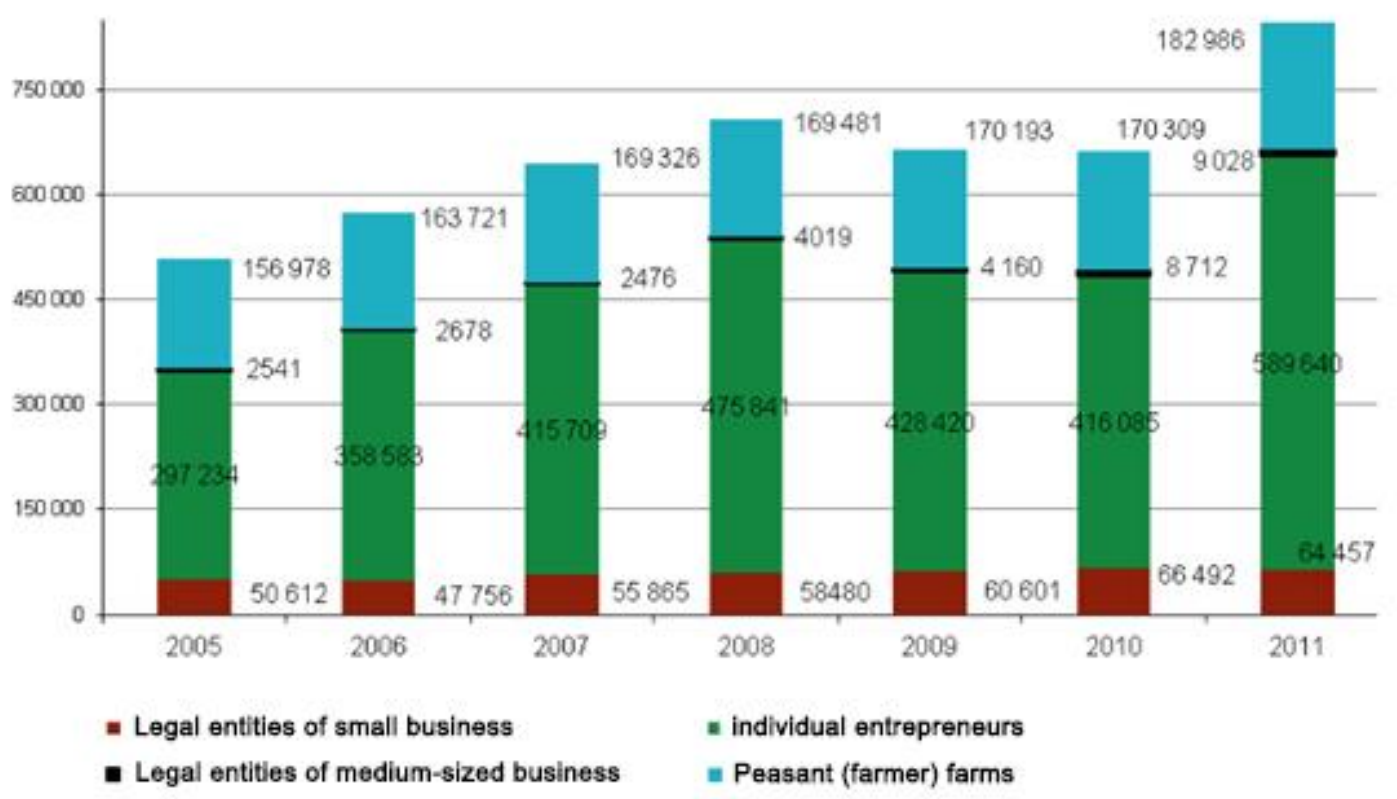

Fig. 3. The number of active SME units 


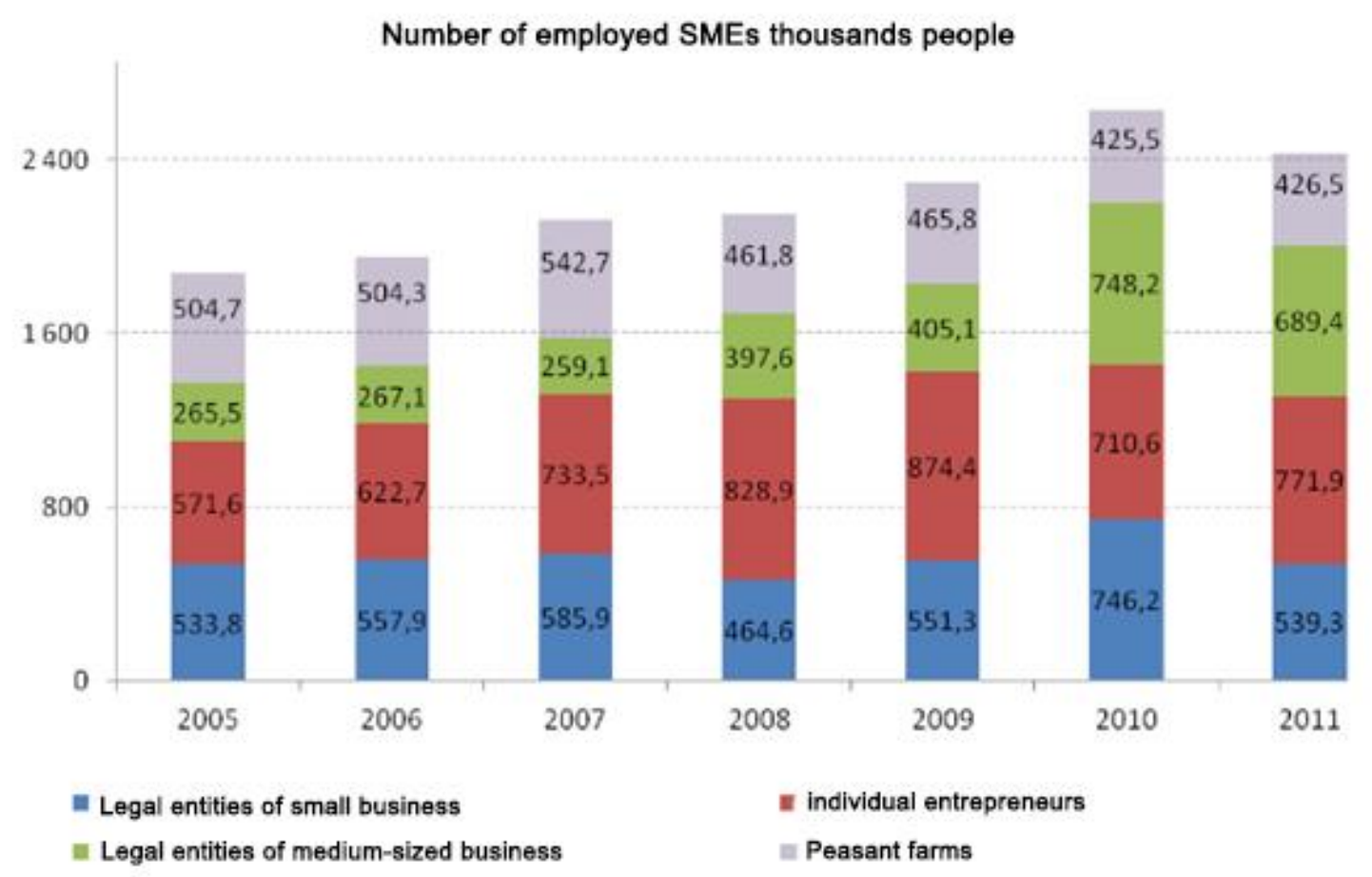

Fig. 4. The number of workplaces is increasing created by small and medium-sized businesses

The World Bank prosecute annual inquiry (Doing Business Report) in which based on 10 indicators assessed the ease of doing business in 183 countries. The number of indicators include: the complexity of starting a business, dealing with construction permits, connection to the power supply system of property registration, taxation, etc.

\section{Investment dynamics in Kazakhstan at the present stage}

Now, in general, difficult stage of world development. It will be a simple making neither in geo-politics nor in the economy for any of the countries.

On January 1, 2016 Kazakhstan living in the new legal and institutional environment. It is formed by the adoption of 59 laws and 400 regulations. For every citizen of Kazakhstan opens new opportunities similar to those which exist in most developed countries world.

Plan' nation accomplishment has allowed the elimination bureaucratic barriers for the development of small and medium enterprises, which is consistent with the country's accession to the leading economic blocs: The World Trade Organization and the Eurasian Economic Union.

Over the past one and half year, revenues from oil and gas sales have fallen sharply, and the energy companies have been forced to abandon their projects in the Caspian region. In the face of this difficult economic situation, the Government of Kazakhstan has developed set of reforms that will enable the country to cope with the problems. As Nazarbayev noted, the country already has successful experience in overcoming economic difficulties (Law of the Republic of Kazakhstan, 1998).

National economies acquired a new investment dynamic. According the rating "Easy Business" our country occupies 41 places among 189 countries. Kazakhstan takes $18^{\text {th }}$ place among 140 countries in labour market efficiency. The "green corridor»is now open for foreign investors. Strategic investors were attracted in the agricultural sector from Germany, Italy and China. Two large dairy farms and factory are going to be builtwith the investors participation in Akmola region. There are also projects for the construction of modern meat processing plants, the total annual power 37 thousand tons of production in East Kazakhstan and Aktobe region, West Kazakhstan and Kostanay area. The total investment in them - about 66 billion tenge (State Program, 20102014). 
There is an organization of the Eurasian multimodal corridor, as a part of global logistics in Kazakhstan. Only the logistics area of Kazakhstan in the Chinese port of Lianyungang sevenfold increase the flow of goods through our territory. The European Commission has lifted all restrictions on flights in EU airline "Air Astana".

There area lot of state-owned enterprises in Kazakhstan: because they account for about $40 \%$ of gross domestic product. In accordance with the October 2016 privatization plan, shares of some state-owned enterprises will be sold on international markets (Decree No. 104, 1998). This will make a qualitative leap towards a more transparent corporate governance, increased competition in the domestic market and successful cooperation with international companies. Shares of many companies, and managed belong to "Samruk_Kazyna", "KazAgro" and holding "Baiterek", will be sold through auctions. All these changes in the economic landscape suggests that a new era has begun in Kazakhstan.

Kazakhstan established a dynamic strategic relationship with international partners and attracts business from all over the world. International ratings confirm that this is one of the most fertile in emerging markets in terms of doing business. Over the past ten years' country attracted more than 215 billion dollarsUSA direct investment, becoming a leader in this indicator in Central Asia (President decree 2003-2015).

Kazakhstan's contribution to the region's economy is growing steadily. In the framework of the "New Silk Road", in particular, are built and developed transport routes that will transform landlocked Kazakhstan to the sea in a link in the bridge between Asia and Western Europe.

At the same time, the International Financial Centre, which is scheduled to create in Astana by 2018, will open the country's banking sector to foreign investment. When it will run a new trial for the consideration of the financial and investment disputes, based on English law.

Maintaining and developing relationships with partners such as the US - a key element of our strategy. US - the second largest source of investment in Kazakhstan.

Removed export barriers, such industries as telecommunications, have become more open to foreign investment.

\section{Conclusion}

Summing up the results of the study can be said that the number of small businesses is growing from month to month, with progressive growth that does not have any jumps and falls, this circumstance characterizes business in the country as a steadily developing. Along with certain operating time in Kazakhstan there are serious problems that require a radical reorganization of the activities in the implementation quality policy. The state affairs in this area now allows us to conclude the backlog of Kazakhstan from the European countries about 12-14 years. It is easy to imagine that if not now begin a purposeful work in this direction, this gap will increase significantly.

The economy of any society is a collection for different activities, which results in the creation for wealth and the consumer movement. This activity is based on the interaction of the productive forces and product relations, characterized by their penetration and inter expression. Business activity also historically arose in the course of development of the society.

As for economic freedom - an important factor in the development of business - it is an economic activity freedom, trade, land use, voluntary co-operation with each other, etc. Economic freedom is equally important for an entrepreneur, a businessman, and for the consumer, because it creates an environment for the creative activity of the person.

The large number of entrepreneurs significantly intensify competition in the national economy and competition, acts known guarantor for deterrence monopolistic trends, inflation, unemployment. Economic mobility, flexibility, decision-making, spatial mobility - all of these features are inherent in the modern enterprise.

Based on the analysis of the course work it should be noted that in the Republic of Kazakhstan received the dynamic development for business in recent years.

\section{References}

Auezkanov, 2009 - Auezkanov, A.B. (2009). Entrepreneurial activity is an objective basis of small business organization. Finances of Kazakhstan. No. 3-4. pp. 73-76. 
Mamyrov, Ikhdanov, 1998 - Mamyrov, N.K., Ikhdanov, Zh. (1998). State regulation of the economy in Kazakhstan (theory, experience, problems). Almaty: The Economy.

Decree No. 104, 1998 - On crediting the development of small and medium-sized businesses, farms, creating jobs. Decree No. 104 the Government of the Republic of Kazakhstan, February 12, 1998. // Collection of legislative acts "Small and medium business: Legislation of the Republic of Kazakhstan. Almaty, 1999.

Law of the Republic of Kazakhstan, 1998 - On unfair competition. Law of the Republic of Kazakhstan, June 9, 1998 №232. // Collection of legislative acts "Small and medium business: Legislation of the Republic of Kazakhstan. Almaty, 1999.

President decree 2003-2015 - President decree of the Republic of Kazakhstan, May 17, 2003 No. 1096 On the Strategy Industrial and Innovative Development of the Republic of Kazakhstan for 2003-2015.

Shirshova, 2011 - Shirshova, L.V. (2011). Analysis for development of small and mediumsized enterprises in the RK. Vestnik. Economic Series. 2011. No. 2. pp. 116-123.

State Program, 2010-2014 - State Program on Forced Industrial and Innovative Development of the Republic of Kazakhstan for 2010-2014.

Voyevutko, 2011 - Voyevutko, A.Y. (2011). State support of small and medium business in Kazakhstan. Finances of Kazakhstan. No. 5. pp. 37-40.

Samruk Kazyna - Samruk Kazyna [Electronic resource]. URL: www.samruk-kazyna.kz 